\title{
Erratum to: Contribution of Tobacco Waste for Agriculture
}

Okta Prima Indahsari and Abul Haris Suryo Negoro

${ }^{1}$ PT. Perkebunan Nusantara X, East Java, Indonesia

${ }^{2}$ University of Jember, East Java,

Original article:

E3S Web Conf.

Volume 142, 2020

The $3^{\text {rd }}$ International Conference on Agriculture and Life Sciences (ICALS 2019)

DOI: $10.1051 / \mathrm{e} 3$ sconf $/ 202014204005$

The entire article start from Introduction should be replaced by the following article in full text:

\footnotetext{
* Corresponding author: haris@unej.ac.id
} 


\title{
Contribution of tobacco waste for agriculture
}

\author{
Okta Prima Indahsari and Abul Haris Suryo Negoro ${ }^{2 *}$ \\ ${ }^{1}$ PT. Perkebunan Nusantara X, East Java, Indonesia \\ ${ }^{2}$ University of Jember, East Java, Indonesia
}

\begin{abstract}
This study aim is to explain the contribution of tobacco waste in the agricultural sector. Tobacco waste here limited to tobacco stems only. Tobacco stems are processed into bio briquettes, pellets, and liquid smoke. Biobriquettes and bio pellets can substitute the use of coal as fuel while liquid smoke can replace the use of chemical insecticides. The three products are eco-friendly and safe for the consumers. The production of these three products is a contribution manifestation of tobacco waste utilization to increase agriculture productivity, reducing fossil energy use, and minimizing tobacco stakeholders from chemical contamination both on tobacco plantation area and tobacco barns.
\end{abstract}

\section{Introduction}

Tobacco commodities have a significant meaning, not only as a source of income for farmers but also for the country. Tobacco plants are seasonal crops, but in the world of agriculture, they are included in the category of plantation crops and are not included in the food crop category [1]. Tobacco plants have a somewhat rounded shape, slightly soft but durable, getting to the ends, smaller. The stem segments have thickened large leaves, stems of branching or slightly branching. In each stem segment, besides overgrown with leaves, it is also green with axillary blade shoots, stem diameter of about $5 \mathrm{~cm}$ [2].

The contribution of tobacco is quite real for the sustainability of plantations in Indonesia. There were seven large tobacco plantation companies during 20162017. The area of large tobacco plantations is 400 ha in 2016 to 700 ha in 2017. The city of smallholder plantations is 155,600 ha in 2016 to 185,000 ha in 2017. Production from smallholder plantations originally 126,400 tons in 2016) increased to 151,800 tons in 2017 [3]. Judging from its exports, East Java Province as a national tobacco barn recorded an export volume of 40,991,842 tons in 2016 and became 49,897,436 tons in 2017, up $21.7 \%$ with a FOB value of USD $367,242,690$ in 2016 to USD 440,672,285 in 2017 or up 20\% [4].

So far, tobacco cultivation has only been oriented towards the production of productive leaves for cigarettes and cigars, while other tobacco organs such as tobacco stems have only become waste [5]. On the other hand, increasing agricultural productivity is necessary. [6], Sustainable agriculture is agriculture whose management is based on meeting needs without compromising the interests of future generations. Efforts that can be made are post-harvest processing and waste management. These activities are not only environmentally friendly but also can increase farmers' incomes.

According [7], Some activities are expected to support and contribute to increasing the benefits of agricultural productivity in the long term, improving environmental quality, including integrated pest control, land conservation, and maintaining water quality. Based on this, the author wants to examine the contribution of products produced by tobacco waste to the plantation sector. The products in question are bio briquettes, biopellet, and liquid smoke.

\section{Experimental section}

\subsection{Materials}

The primary material used in this research is tobacco stems. The tools and supporting materials needed for briquetting and liquid smoke were as follows: reactor for making biochar and liquid smoke at once, whereas biochar is the raw material for briquettes, and stem powder is the raw material for biopellets. Cassava starch used as adhesive, disk mill, and semi-manual press are used to briquettes and biopellets's mold. The briquette semi-manual press contains 10 cylinder forms, which is each cylinder form has a diameter $4 \mathrm{~cm}$ and $6 \mathrm{~cm}$ height. The materials and equipment showed in Figure 1 and Figure 2.

\subsection{Methods}

This research uses quantitative and qualitative research methods. For quantitative research, use proximate and ultimate analysis also GCMS. The proximate analysis of bio briquettes regarding [8] for the moisture content, [9] for the volatile matter, [10] for the ash content, [11] for 
the fixed carbon, [12] for the total sulphur. The ultimate analysis of bio briquettes is accorded to [13] for the calorific value. The proximate analysis of bio pellets regarding [14] for the ash content, [15] for the fixed carbon, [16] for the moisture content, and [17] for the volatile matter. The ultimate analysis for bio pellets are [18] for the calorific value and [19] for the bulk density. Both describe and analyze the application of tobacco waste products to raise agriculture productivity and a positive impact on the environment.

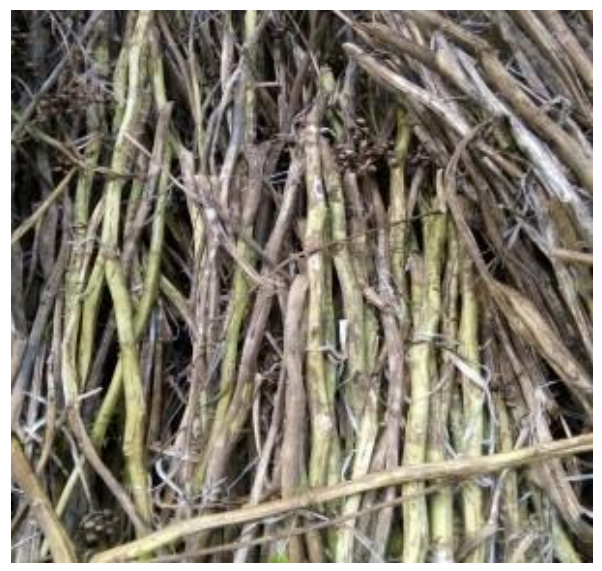

Fig. 1. Tobacco Stems

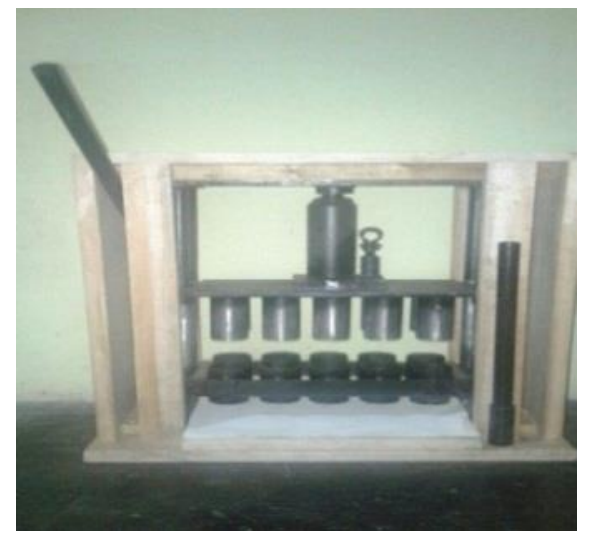

Fig. 2. Semi Manual Press with 10 cylinders form holes

\section{Results and discussion}

Increasing the use of waste into new products that have high economic value is one solution to reduce the number of industrial residues [20]. Waste on tobacco plantations, which are abundant but not yet utilized optimally is tobacco stems. The tobacco stem in this study processed into bio briquettes, pellets, and liquid smoke.

\subsection{Biobriquettes}

Indahsari [21] state that 23 percent national energy comes from new and renewable energy and its 8.3 percent comes from bioenergy. The use of coal briquettes, in addition to being classified as nonrenewable fossil fuels, also has significant health impacts if the space using coal briquettes does not have sufficient ventilation. According to Environment Minister Number 45 of 1997, there are five standard air pollution index (ISPU) parameters, namely: PM 10 (particulates), CO (carbon monoxide), SO (sulfur oxide), NO (nitrogen oxide), and ozone. If it exceeds the threshold, it will have an impact on the health of human and animal respiratory organs and plant sensitivity.

The effort to minimize the impact caused by the use of coal briquettes is the use of biomass briquettes from tobacco stems. The bio-briquettes are described in Figure 3 below.

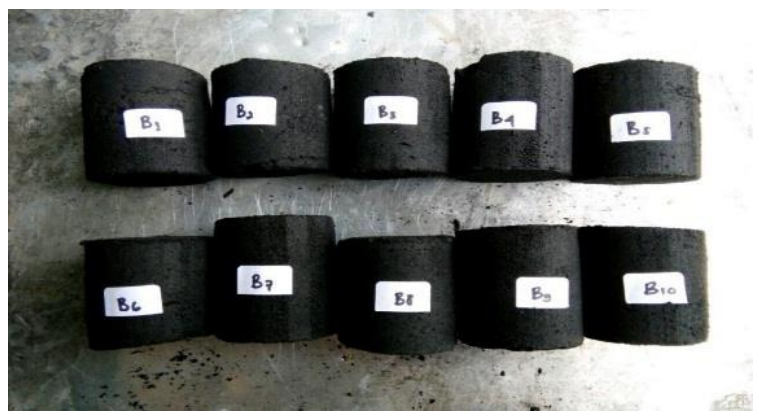

Fig. 3. Bio-briquettes

The bio-briquettes samples tested on five times repetition and calculate the average value (mean). The mean of proximate analysis of bio briquettes consist of water content was $8.51 \%$, the volatile matter was $45.56 \%$, ash content was $8.82 \%$, fixed carbon was $36.30 \%$, sulfur content was $0.75 \%$. The mean of ultimate analysis was bulk density was $0.38 \mathrm{gr} / \mathrm{cc}$, the calorific value was $4,437.4 \mathrm{cal} / \mathrm{gr}$, flammable duration was 636.8 minutes, whereas coal briquettes only reach 531 minutes.

The process of converting residues into a densified form has some benefits - it helps to solve the problem of residue disposal, thereby reducing pollution due to waste disposal; usage of briquettes instead of coals results in reducing a considerable amount of emission of pollutants into the environment; the process is cost-effective because raw materials for this process are derived from waste resources; it creates employment opportunities to the rural people [22].

\subsection{Biopellets}

Bio pellet or pellet derived from biomass with onverted and can be used as fuel energy using densification techniques. This technique aims to increase the density (density) of the material and facilitate storage and transportation. Biomass conversion can increase the calorific value per unit volume, easily stored and transported, has the size, and uniform quality of the bio pellet produced. The main factors that influence the strength and durability of pellets are raw materials, moisture content, particle size, compressive conditions, the addition of adhesives, exfoliation tools, and treatment after the production process [23]. The pellets showed in Figure 4. 


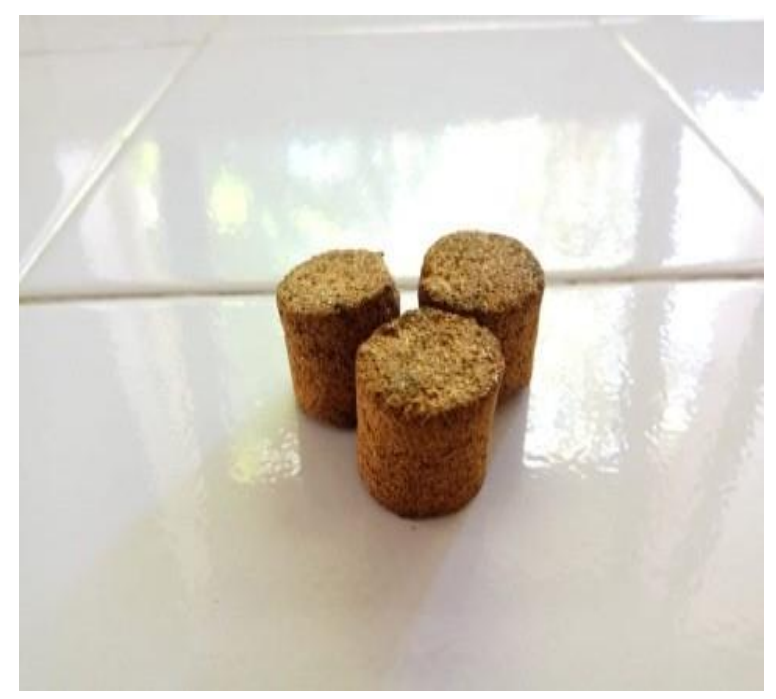

Fig. 4. Biopellets with diameter $4 \mathrm{~cm}$ and $6 \mathrm{~cm}$ height

The pellets samples tested on five times repetition and calculate the average value (mean). The mean of proximate analysis of bio pellets consist of water content was $3.9 \%$, the volatile matter was $87.75 \%$, ash content was $5.75 \%$, fixed carbon was $2.77 \%$. The mean of ultimate analysis was bulk density was $0.50 \mathrm{gr} / \mathrm{cc}$, the calorific value was $4,793.78 \mathrm{cal} / \mathrm{gr}$, bio pellet consumption speed was $0.24 \mathrm{~kg} / \mathrm{hour}$, and weight of ash was $0.232 \mathrm{~kg}$.

The development of pellets from tobacco waste is not only useful to minimize solid waste in the garden but also can create energy independence for tobacco plantations [24].

\subsection{Liquid Smoke}

Liquid smoke is a food additive came from pyrolyzed biomass which conveniently provides a smoked flavor and aroma to marinated food items. A variety of plant sources have been used to improve liquid smoke since the properties, such as the smell, are dependent on the reference [25].

In agriculture, liquid smoke is used to improve soil quality and neutralize acidic soil, kill plant pests and control plant growth, insect repellents, accelerate growth in roots, stems, tubers, leaves, flowers, and fruit. Thus liquid smoke is believed to be able to replace the function of chemical pesticides which are very dangerous for health and the environment.

Yuanita and Virdawan [26] conducted a trial of the utilization of liquid smoke from tobacco stem waste to overcome the caterpillars Spodoptera litura, which has 1-5 instar larvae. In laboratory-scale testing using one instar larvae with a size $<0.5-1.5 \mathrm{~cm}$, which was carried out through $3 \times$ tests with a concentration of $2 \%$. Liquid smoke is sprayed directly on the instar, and some are scattered indirectly through insect net. The results showed that the use of liquid smoke by spraying on waring was more effective than spraying directly on caterpillars, but with a not too far different. This indicates that liquid smoke can be used as an antipathogen in the form of S. litura.
Based on laboratory tests, the use of liquid smoke for the control of Spodoptera litura caterpillars (instar first larvae) can show the percentage of $100 \%$ caterpillar deaths in approximately one week of observation. So that in the follow-up study, it is necessary to test the larvae above the 1 st instar larvae and can also be carried out on a field-scale test.

Liquid smoke plays a role in the latex clotting process. Liquid smoke is a by-product of charcoal burning that is the crude condensate of smoke generated during the process of making wood charcoal. There are more than 200 water-soluble compounds such as alcohol, phenolic, alkane, organic acids, and ester compounds. Liquid smoke has well-known uses as antimicrobial. There was presented the use of liquid smoke as coagulating and antifungal agents for latex [27]. Therefore liquid smoke has the potential for use as a natural antimicrobial in industrial applications where the smoke flavour is desired. As an all-natural food preservative, the concentration of liquid smoke can could be adjusted to the need, and essential volatile compounds are easily controlled [28].

When stems char made, the smoke was burnt to the pipes and condensed. Therefore, the gas phase from smoke changed into a liquid phase and became liquid smoke. So, from one reactor, the author got two products at once, there was biochar as raw material for bio briquettes and tobacco liquid smoke. The process of making a new product is channeled and made into a unique advantage product. In other words, the making of briquettes and liquid smoke is not only reduced by the solid waste in tobacco plantations but also minimizing water pollution in the environment. The Visualization of tobacco liquid smoke is presented in Figure 5.

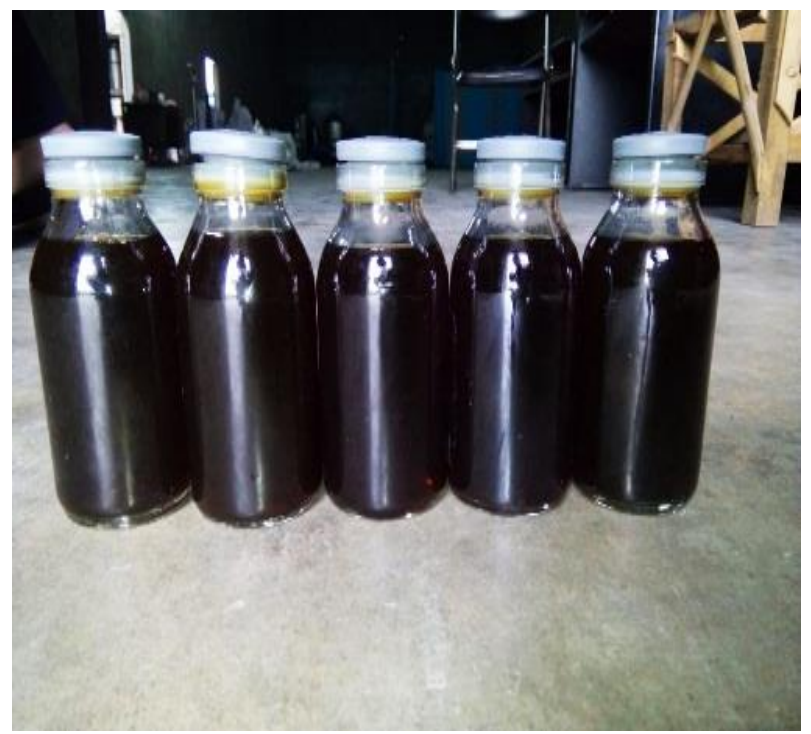

Fig. 5. Liquid Smoke

To know chemical compounds of tobacco liquid smoke, it analyzed use GC MS. The result as chromatogram is shown in Figure 6. 


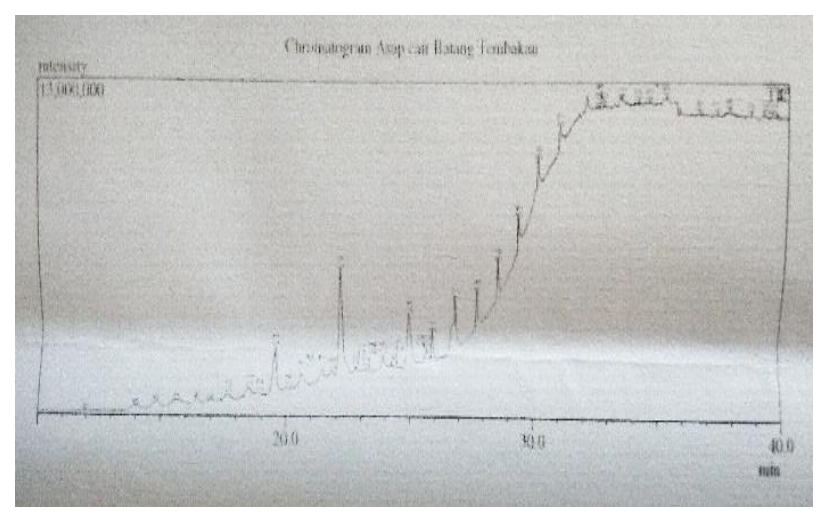

Fig. 6. Chromatogram of Liquid Smoke

A chemical compound of tobacco liquid smoke is phenol, aldehyde, ketone, organic acid, alcohol, and ester. Jyh et al. [29] state that the potent antimicrobial activity of liquid smoke was correlated to the high contents of organic acids and phenolic compounds.

\section{Conclusion}

Tobacco stems as tobacco waste could be processed into valuable products, such as bio briquettes, pellets, and liquid smoke. Both bio briquettes and bio pellets could substitute utilization charcoal briquettes. On the other hand, tobacco liquid smoke could replace chemical insecticide into organic insecticide that well known ecofriendly. They support on reduce utilization of fossil fuel, minimize air pollution, and decrease releasing chemical contaminants to the environment.

\section{References}

1. M. Ali. Pengaruh Dosis Pemupukan NPK Terhadap Produksi dan Kandungan Capsaicin pada Buah Tanaman Cabe Rawit (Capsicum frutescens L.). Jurnal Agrosains: Karya Kreatif Dan Inovatif 2(2), 171-178 (2015).

2. M. Ali, B. W. Hariyadi. Teknik Budidaya Tembakau. Fakutas Pertanian Agroteknologi Universitas Merdeka Surabaya (2015).

3. Badan Pusat Statistik. Statistical Yearbook of Indonesia 2018. Badan Pusat Statistik. Jakarta (2018).

4. Badan Pusat Statistik Jawa Timur. Jawa Timur Province in Figures. Badan Pusat Statistik Jawa Timur. Surabaya (2018).

5. O. P. Indahsari. Briquettes From Tobacco Stems As The New Alternative Energy. J. Kim. Terap. Indones. 19(2), 73-80 (2017).

6. C. Thirtle, L. Lin, J. Piesse. the impact of researchled agricultural productivity growth on poverty reduction in Africa, Asia, and Latin America. World Development 31(12), 1959-1975 (2003).

7. A. B. Basri. Manfaat Asap Cair untuk Tanaman. Serambi Pertanian 4(5), 2 (2010).

8. ASTM D-3173 Standard Test Method for Moisture in The Analysis Sample of Coal and Coke
9. ASTM D-3175-11) Standard Test Method for Volatile Matter in the Analysis Sample of Coal and Coke

10. ASTM D-3174-12 Standard Test Method for Ash in the Analysis Sample of Coal and Coke from Coal

11. ASTM D-3172-13 Standard Practice for Proximate Analysis of Coal and Coke

12. ASTM D-3177-02 Standard Test Methods for Total Sulfur in the Analysis Sample of Coal and Coke

13. (ASTM D-5865-13) Standard Test Method for Gross Calorific Value for Coal and Coke

14. ASTM D-1102 Standard Test Method for Ash in Wood

15. ASTM D-3172 Standard Test Method for Proximate Analysis of Coal and Coke

16. ASTM E-871 Standard Test Method for Moisture Analysis of Particulate Wood Fuels

17. EN-15148 Solid Biofuels - Determination of The Content of Volatile Matter

18. ASTM-E711 Standard Test Method for Gross Calorific Value of Refuse-Derived Fuel by Bomb Calorimeter

19. ASTM E-873 Standard Test Method for Bulk Density of Densified Particulate Biomass Fuels.

20. R. Damayanti, N. Lusiana, J. Prasetyo. Study Effect of Particle Size and Tapioca Starch Addition on Biopelet Characteristic from Cacao Shell (Theobroma cacao L.) as Alternative Renewable Fuel. Jurnal Teknotan 11(1), 51-60 (2017).

21. O. P. Indahsari. Kajian Varian Bahan Perekat Terhadap Kualitas Pellet Batang Tembakau. Seminar Nasional Tembakau: Meningkatkan Nilai Tambah Dan Daya Saing Tembakau Melalui Standardisasi, Pengaturan Kelembagaan dan Diversifikasi Produk Dalam Menyongsong Era Revolusi Industri 4.0 (2018).

22. A. Tamilvanan. Preparation of biomass briquettes using various agro-residues and waste papers. Journal of Biofuels. 4(2), 47-55 (2013).

23. B. Lehmann, H. W. Schroder, R. Wollenberg, J. U. Repke. Effect of miscanthus addition and different grinding processes on the quality of wood pellets. Biomass Energy 44, 150-159 (2012).

24. O. P. Indahsari. Biopellet Berbasis Limbah Tembakau. Prosiding Seminar Nasional Pembangunan Pertanian III: Sumberdaya dan Kebijakan Pembangunan Pertanian di Era Revolusi Industri 4.0 (2018).

25. J. I. B. Janairo, D. M. Amalin. Volatile chemical profile of cacao liquid smoke. International Food Research Journal 25(1), 213-216 (2018)

26. N. Yuanita, Y. V. Virdawan. Testing Technology of Liquid Smoke Tobacco Stem Against Caterpillar Spodoptera Litura on Laboratory Scale. Prosiding Seminar Nasional II: Peranan Riset dan Inovasi Teknologi Berbasis Sumber Daya Alam Terbarukan Mendukung Industri 4.0. Balai Riset dan Standardisasi Industri Samarinda (2019).

27. P. Sumanatrakula, P. Kongsunea, L. Chotitama, U. Suktoa. Utilization of dendrocalamus asper backer bamboo charcoal and pyroligneus acid. Energy Procedia 79. 691-696(2015) 
28. J. M Lingbeck, P. Cordero, C. A. O’Bryan, M. G Johnson, S. C. Ricke, P. G. Crandall. Functionality of liquid smokeas an all-natural antimicrobial in food preservation. Meat Sci. Jun; 97 (2). 197-206 (2014) DOI: 10.1016/j.meatsci.2014.02.003.

29. F. Y. Jyh, H. Y. Cheng, T. L. Ming, W. W. Yuh, Y. C. Li, Chemical composition, antioxidant, and antibacterial activity of wood vinegar from litchi chinensis. Molecules (21) 1150 (2016); DOI: 10.3390/molecules21091150 